\title{
Saxiloba: a new genus of placodioid lichens from the Caribbean and Hawaii shakes up the Porinaceae tree (lichenized Ascomycota: Gyalectales)
}

\author{
Robert Lücking ${ }^{1 *}$, Bibiana Moncada², Harrie J. M. Sipman, Priscylla Nayara \\ Bezerra Sobreira ${ }^{3}$, Carlos Viñas ${ }^{4}$, Jorge Gutíerrez ${ }^{4} \&$ Timothy W. Flynn $^{5}$
}

\section{Article info}

Received: 5 Mar. 2020

Revision received: 22 Apr. 2020

Accepted: 30 Apr. 2020

Published: 29 Dec. 2020

\section{Associate Editor}

Cécile Gueidan

\begin{abstract}
The new genus Saxiloba is described with the two species S. firmula from the Caribbean and $S$. hawaiiensis from Hawaii. Saxiloba is characterized by a unique, placodioid thallus forming distinct lobes, growing on rock in shaded to exposed situations with a trentepohlioid photobiont and a fenestrate thallus anatomy with distinct surface lines. The material is often sterile, but Porina-like perithecia and ascospores had previously been described for the Caribbean taxon and were here confirmed for both species. Molecular sequence data also confirmed placement of this lineage in Porinaceae. Its position within that family supports the notion that Porinaceae should be subdivided into a larger number of genera than proposed in previous classification attempts. Compared to other Porinaceae, Saxiloba exhibits a unique morphology and anatomy that recalls taxa in the related family Graphidaceae and it substantially expands the known phenotypic variation within Porinaceae. The two recognized species are similar in overall morphology but, apart from their disjunct distribution and different substrate ecology, differ in lobe configuration, color and disposition of the crystal clusters and resulting surface patterns.
\end{abstract}

Key words: Labyrintha, Leucodecton, Poeltidea, Trichotheliaceae, window lichens

\section{Introduction}

Island ecosystems exhibit high levels of endemism, often harboring unique phenotypes (Magnusson \& Zahlbruckner 1945; Johnson \& Raven 1973; Wagner \& Funk 1995; Pax et al. 1997; Morden et al. 2003). Archipelagos such as Hawaii and Galapagos, but also the Caribbean, are known for striking evolutionary radiations in vascular plants and vertebrates (Carlquist et al. 2003; O'Grady \& DeSalle 2008; Parent \& Crespi 2009; Givnish et al. 2009; Tye \& Francisco-Ortega, J. 2011; Lerner et al. 2011; Knope et al. 2012). In contrast, island lichen biota are generally considered low in endemism with rates estimated between 10\% and 30\% (Weber 1986; Eldredge \& Miller 1995; Aptroot \& Bungartz 2007; Smith 2013). However, recent

\footnotetext{
${ }^{1}$ Botanischer Garten und Botanisches Museum, Freie Universität Berlin, Königin-Luise-Straße 6-8, 14195 Berlin, Germany

2 Licenciatura en Biología, Universidad Distrital Francisco José de Caldas, Cra. 4 No. 26D-54, Torre de Laboratorios, Herbario, Bogotá D.C., Colombia

${ }^{3}$ Departmento de Micologia, Universidade Federal de Pernambuco, Av. Nelson Chaves s/n, Recife, PE 50670-420, Brasil

${ }^{4}$ Jardín Botánico Nacional, Carretera del Rocío km 31⁄2, Calabazar, 19230 Habana, Cuba

${ }^{5}$ National Tropical Botanical Garden, 3530 Papalina Road, Kalaheo, HI 96741 USA

* Corresponding author e-mail: r.luecking@bgbm.org
}

molecular approaches and detailed morphological revisions suggest the opposite with endemism in lichen fungi often comparable to that of vascular plants (Moncada et al. 2014, 2017; Bungartz et al. 2016; Dal Forno et al. 2017; Lücking et al. 2017; Mercado-Díaz et al. 2020).

During a survey of three islands in Hawaii in 2013 to sample lichen material for molecular studies, RL and BM revised collections held at the National Tropical Botanical Garden herbarium (PTBG), including a strange lichen collected by TWF 24 years ago on shaded basalt on the island of Kauai. The taxonomic affinities of this lichen remained unresolved until similar material was found rather abundantly on shaded calcareous rock outcrops during an expedition to western Cuba (Pinar del Río) in April 2016, by RL, BM , CV and JG . While the overall morphology and anatomy of the two lichens suggested affinities with certain Graphidaceae, in particular the genera Leucodecton and Sanguinotrema (Frisch et al. 2006; Rivas Plata et al. 2010; Lücking et al. 2015), molecular sequence data unexpectedly placed the Cuban taxon within Porinaceae. Careful search for ascomata indeed revealed the presence of perithecia in a few specimens, producing 3-5-septate ascospores. Revision of taxa historically described from Cuba, as part of a checklist project 
together with $\mathrm{CV}$ and HJMS, turned up two names under which the lichen had been previously described, namely Verrucaria firmula Nyl. (Nylander 1892; nom. inval.) [三 Porina firmula Nyl. ex Müll. Arg. (Müller 1885)] and Endopyrenium incrassatum Müll. Arg. (Müller 1885) [三 Dermatocarpon incrassatum (Müll. Arg.) Zahlbr.].

Porinaceae (syn.: Trichotheliaceae) is one of the dominant families of tropical crustose lichens, found mostly on bark and leaves in shady, wet forests, but also frequently on rocks (Aptroot \& Sipman 1993; McCarthy 1993, 1995, 2001, 2003; Makhija et al. 1994; Lücking 1998; Lücking \& Vězda 1998; Rivas Plata et al. 2008; Aptroot \& Cáceres 2013; Harada 2015, 2016). Relatively few taxa occur in temperate regions. Species in this family are characterized by a thin, crustose, compact thallus with a trentepohlioid photobiont and by perithecioid ascomata with unbranched paraphyses, thin-walled, unitunicate asci, and hyaline ascospores with thin walls and septa (Aptroot \& Sipman 1993; McCarthy 1993, 2001; Lücking 2008). Together with Coenogoniaceae and Gyalectaceae, Porinaceae, which also includes Myeloconidaceae (McCarthy \& Elix 1996; Nelsen et al. 2014), is now placed in the resurrected order Gyalectales. The latter is sister to the also resurrected order Graphidales including Graphidaceae and Gomphillaceae (Grube et al. 2004; Baloch et al. 2010; (Kraichak et al. 2018; Lücking 2019).

Whereas Porinaceae is well-delimited at family level, both phenotypically and phylogenetically, its internal classification has been the subject of much debate with proposals ranging from recognizing few genera only, including a single large genus, Porina (Lücking 1998, 2008; Lücking et al. 2017), to distinguish several smaller genera characterized by perithecial morphology and thallus characters (Hafellner \& Kalb 1995; Harris 1995, 2005; McCarthy \& Malcolm 1997). Molecular sequence data support the separation into smaller genera, but the phenotypes hitherto distinguished at genus level do not necessarily form monophyletic groups, and many taxa have not yet been sampled (Baloch \& Grube 2006, 2009; Nelsen et al. 2014). Along with the recent recognition of a new genus, Flabelloporina, a possible future generic concept for Porinaceae was outlined (Sobreira et al. 2018). The placement of the newly discovered lineage further supports this solution. Also, the two lichens treated here add a new phenotype to the known morphological variation of this family. Since the phylogenetic analysis supports the uniqueness of this lineage, it is here described as a new genus, Saxiloba.

\section{Material and methods}

The sequenced material was collected in the province of Pinar del Río in westernmost Cuba, during a field trip by RL, BM, CV, and JG; voucher specimens are deposited in B and HAJB. The new sequences for this study were generated using the Sigma REDExtract-NAmp Plant PCR Kit (St. Louis, Missouri, SA) for DNA isolation, following the manufacturer's instructions but with lower proportions for lower amounts of DNA. We targeted both the mitochondrial small subunit (mtSSU)
Table 1. GenBank accession numbers for the sequence data used in this study.

\begin{tabular}{|c|c|c|c|}
\hline Genus & Species & $\begin{array}{c}\text { mtSSU } \\
\text { accession }\end{array}$ & $\begin{array}{c}\text { Country or } \\
\text { Territory }\end{array}$ \\
\hline Coenogonium & leprieurii & AY584698 & \\
\hline Coenogonium & luteum & AY584699 & \\
\hline Coenogonium & pineti & AY300884 & \\
\hline Myeloconis & erumpens & KJ449328 & New Caledonia \\
\hline Myeloconis & fecunda & KJ449325 & Brazil \\
\hline Myeloconis & guyanensis & KJ449326 & Puerto Rico \\
\hline Porina & aenea & KR108906 & Wales \\
\hline Porina & alba & DQ168371 & Costa Rica \\
\hline Porina & atrocoerulea & DQ168390 & Costa Rica \\
\hline Porina & austroatlantica & KR108903 & Falkland Islands \\
\hline Porina & byssophila & KR108911 & Wales \\
\hline Porina & chlorotica & KR108908 & Ireland \\
\hline Porina & cryptostoma & KJ449308 & Costa Rica \\
\hline Porina & dolichophora & KJ449306 & Costa Rica \\
\hline Porina & epiphylla & DQ168374 & Costa Rica \\
\hline Porina & exasperatula & KJ449316 & Panama \\
\hline Porina & exocha & KF833333 & Australia \\
\hline Porina & farinosa & KJ449311 & Panama \\
\hline Saxiloba & firmula & MT371252 & $\begin{array}{l}\text { Cuba 41891 } \\
\text { (piece 'd'); } \\
\text { DB22547 }\end{array}$ \\
\hline Saxiloba & firmula & MT371253 & $\begin{array}{l}\text { Cuba } 41891 \\
\text { (piece 'f'); } \\
\text { DB22548 }\end{array}$ \\
\hline Porina & guianensis & DQ168384 & Costa Rica \\
\hline Porina & heterospora & KJ449318 & Brazil \\
\hline Porina & imitatrix & KJ449315 & Panama \\
\hline Porina & karnatakensis & DQ168376 & Costa Rica \\
\hline Porina & lectissima & DQ168414 & Austria \\
\hline Porina & limbulata & AY648893 & Costa Rica \\
\hline Porina & lucida & DQ168377 & Costa Rica \\
\hline Porina & mastoidea & DQ168382 & Costa Rica \\
\hline Porina & nitidula & DQ168392 & Costa Rica \\
\hline Porina & nucula & KJ449310 & Costa Rica \\
\hline Porina & pacifica & KT254300 & Canada \\
\hline Porina & papillifera & DQ168396 & Costa Rica \\
\hline Porina & radiata & DQ168386 & Costa Rica \\
\hline Porina & repanda & DQ168393 & Costa Rica \\
\hline Porina & rubentior & DQ168405 & Costa Rica \\
\hline Porina & rufula & DQ168407 & Costa Rica \\
\hline Porina & subepiphylla & DQ168380 & Costa Rica \\
\hline Porina & subnitidula & DQ168394 & Mexico \\
\hline Porina & tetracerae & KJ449314 & Panama \\
\hline Trichothelium & annulatum & DQ168415 & Mexico \\
\hline Trichothelium & epiphyllum & DQ168416 & Costa Rica \\
\hline Trichothelium & pallidisetum & AY648900 & Costa Rica \\
\hline
\end{tabular}

and the nuclear large subunit rDNA (nuLSU), but only obtained sequences for the former; previous work suggests that nuLSU sequences are notoriously difficult to obtain for members of this family (Nelsen et al. 2014). The mtSSU was amplified using the primers SSU1R and SSU3R (Zoller et al. 1999). The 13- $\mu \mathrm{L}$ PCR reactions consisted of $6.0 \mu \mathrm{L}$ of water, $0.1 \mu \mathrm{L}$ of each PCR primer, $3.5 \mu \mathrm{L}$ of REDExtract-n-AmpPCRReady Mix (SigmaAldrich) and 2.0 $\mu \mathrm{L}$ DNA. The PCR cycling conditions 
were as follows: $95^{\circ} \mathrm{C}$ for $5 \mathrm{~min}$, followed of 35 cycles at $94^{\circ} \mathrm{C}$ for $45 \mathrm{~s}$, after $50^{\circ} \mathrm{C}$ for $1 \mathrm{~min}, 72^{\circ} \mathrm{C}$ for $1.5 \mathrm{~min}$, followed by a single $72^{\circ} \mathrm{C}$ final extension for $10 \mathrm{~min}$.

Prior to assembly, the obtained sequence reads were evaluated using BLASTn (Chen et al. 2015) and combined with selected sequences of Porinaceae from GenBank, using Coenogonium as outgroup (Table 1). All sequences were arranged in BIOEDIT 7 (Hall 1999) and aligned using MAFFT 7 (Katoh \& Standley 2013). The phylogenetic tree was built by means of maximum likelihood with 1000 bootstrap pseudoreplicates using RAxML 8 (Stamatakis 2014). The best-scoring tree was visualized in FigTree 1.4 (Rambaut \& Drummond 2012).

\section{Results and discussion}

Although based on a single marker, the mitochondrial small subunit rDNA (mtSSU), the molecular phylogeny of Porinaceae was well-resolved and supported including in the backbone (Fig. 1). Overall the topology was congruent with that obtained by Sobreira et al. (2018). The family formed two large clades with $77 \%$ and $70 \%$ support, respectively. One contained taxa with exposed, black or red perithecia, the other those with perithecia covered by thallus, except for the black-fruited Porina byssophila lineage, which clustered with support with
Clathroporina and Myeloconis. Besides perithecial wall pigmentation, the lineages in the first large clade were largely distinguished by substrate (leaves vs. bark vs. rock) and biome ecology (tropical vs. temperate); most of these have generic names available. For instance, blackfruited tropical species on leaves clustered in the genus Trichothelium, whereas temperate-subtropical species on bark and rock, including aquatic taxa, formed separate lineages (Pseudosagedia, P. pacifica clade). Similarly, red-fruited, tropical, foliicolous species formed a lineage (Phragmopeltheca) separate from temperate, corticolous taxa (Segestria). In the clade characterized by thallus-dominated perithecial verrucae, lineages were chiefly separated by ascospore septation (muriform in Clathroporina and Myeloconis) and shape (narrow filiform in the $P$. dolichophora clade), as well as habitat ecology, thallus morphology and substrate (Porina s.str., Phyllophiale, P. guianensis clade, Phylloporina).

The unique, placodioid taxon from Cuba, Saxiloba firmula, was placed in the first large clade, which is congruent with its red perithecia (present in few specimens) resembling those of Phragmopeltheca and Segestria. However, it formed a strongly supported lineage on a long branch separate from the latter two, and monophyly of these three lineages was rejected with high significance (SH test employed in RAxML 8; $<<0.001$ ). Together

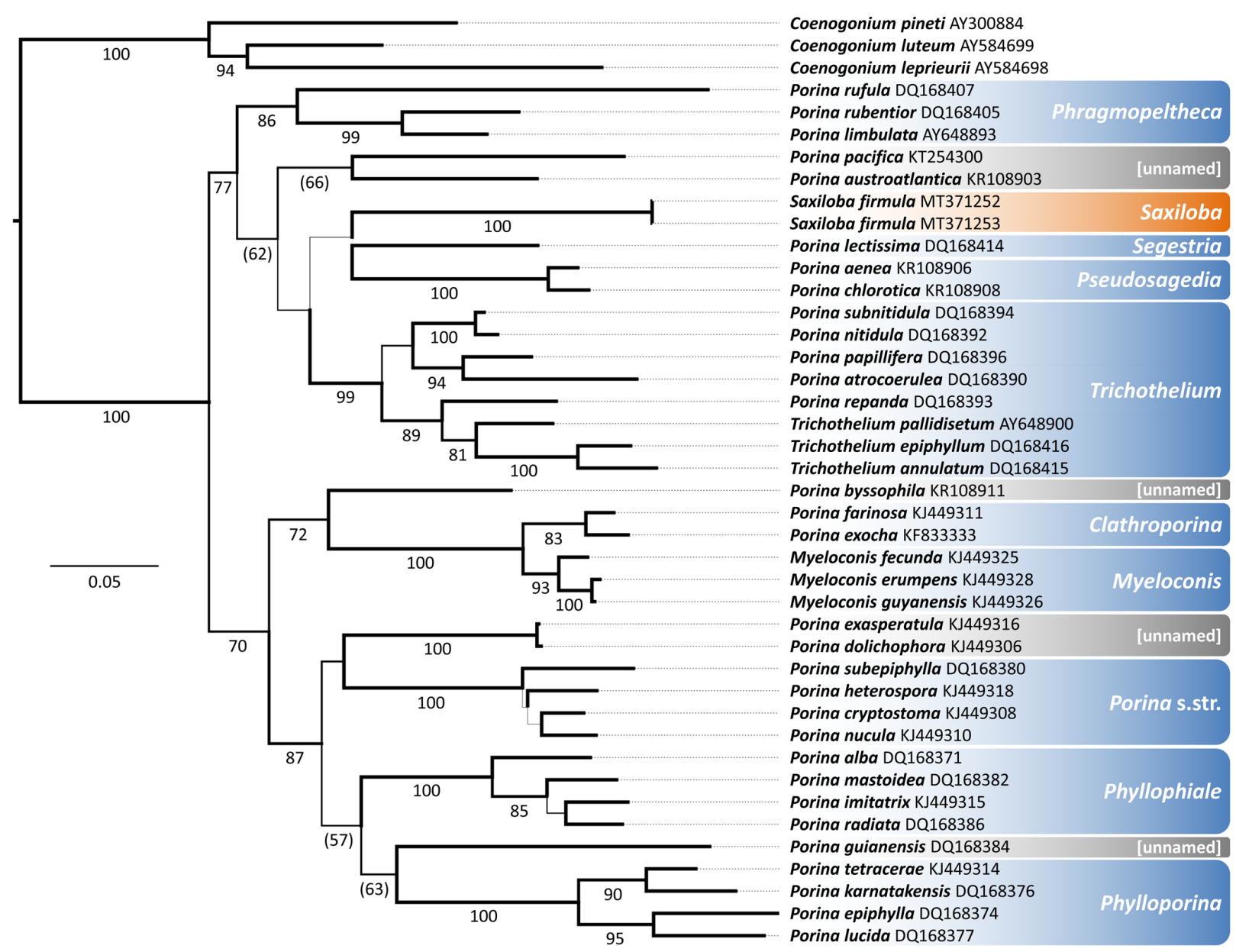

Figure 1. Best-scoring maximum-likelihood tree of Porinaceae based on the mtSSU marker, showing the position of the new genus Saxiloba within the context of newly recognized genus-level clades. Clade labels follow Sobreira et al. (2018). Some smaller clades partly consisting of singletons have no names available. 
with the unique thallus morphology within the genus, we conclude that this lineage should be recognized at genus level, and introduce the genus Saxiloba for it.

\section{Taxonomy}

Saxiloba Lücking, Moncada \& Viñas, gen. nov. (Figs 2-3)

MycoBank MB 835479

Diagnosis: A new genus in the family Porinaceae, characterized by a placodioid thallus with clusters of columnar crystals visible from above areoles separated by a network of reticulate to meandering lines with reddish perithecia and with small, transversely septate ascospores, growing on rock.

Generic type: Saxiloba firmula (Nyl. ex Müller) Lücking, Moncada \& Viñas.

Description. Thallus saxicolous, placodioid, convex with distinct marginal lobes, but densely appressed to the substrate; surface smooth, but with a distinct network of reticulate to meandering lines (best seen when hydrated). Photobiont Trentepohlia. Thallus in section with large, triangular to rhomboid crystal clusters embedded into the photobiont layer (somewhat appearing like teeth within gums), the photobiont layer developed horizontally beneath and vertically between the crystal clusters; above with a prosoplectenchymatous cortex and below with a medulla and a thick, dark brown hypothallus layer. Perithecia immersed to erumpent or somewhat prominent, largely covered by thallus, ostiolar area orange-red to cherry-red or dark reddish brown, lacking a thallus cover and slightly translucent; paraphyses and asci as in other genera of the family. Ascospores transversely 3-5-septate, small.

Etymology. Referring to the placodioid thallus with distinct marginal lobes, apparently growing exclusively on rock.

Distribution and ecology. Thus far only known from disjunct collections on islands in the Caribbean (Cuba, Isla de la Juventud, Puerto Rico) and the Hawaiian archipelago (Kauai); growing on calcareous or volcanic rock in shady to exposed situations.

Notes. Within Porinaceae, the new genus Saxiloba is readily distinguished by its placodioid thallus with columnar clusters of crystals embedded in a network of reticulate to meandering lines when seen from above. The unique thallus morphology and anatomy corresponds to its phylogenetic position on a separate, rather long branch. Notably, the largely thallus-covered perithecia of Saxiloba firmula resemble those of the larger second clade of the family, whereas those of $S$. hawaiiensis are more similar to those of red-fruited foliicolous species in the Phragmopeltheca clade.

Except for the occasionally present perithecia, which immediately reveal its systematic affinities, the genus would not be considered a member of Porinaceae, but bears resemblance with lichens in some other related and unrelated families. Most similar are certain species in the genus Leucodecton in the related family Graphidaceae, in particular L. phaeosporum (Rivas Plata et al. 2010; Rivas Plata \& Lumbsch 2011), which are readily distinguished by the apothecioid, pore-like ascomata with apically thick-walled asci forming brown, muriform ascospores, and in the sterile state by the absence of distinct marginal lobes.

The particular thallus anatomy found in Saxiloba can be compared to what has been coined 'window lichens' ('Fensterflechten'; Vogel 1955; Follmann 1965), in analogy to the 'stone plants' ('Fensterpflanzen') in the former family Mesembryanthemaceae (now Aizoaceae). This anatomy was redescribed in much detail from a presumably monospecific genus, Labyrintha implexa (Malcolm et al. 1995), recently recombined as Poeltidea implexa (Fryday \& Hertel 2014), a rock-dwelling taxon in the unrelated family Lecideaceae. Malcolm et al. (1995) made no reference of the earlier treatments of 'window lichens' by Vogel (1995) and Follmann (1965), but Vondrák \& Kubásek (2013) and Fryday \& Hertel (2014) showed that this anatomy appears to have evolved in several unrelated lineages, although it is not frequent. Vertical stacks of algal cells separated by columnar crystal clusters or vertical stacks of fungal hyphae have been interpreted as adaptation to xeric habitats and/or high solar insolation (Vondrák \& Kubásek 2013; Fryday \& Hertel 2014). This hypothesis seems to fit the Hawaiian species, Saxiloba hawaiiensis, whereas S. firmula grows more frequently in shady conditions. Under such conditions, one could also imagine the vertical crystals to aid in light distribution across a thicker photobiont layer, thus enabling the accumulation of higher biomass under low light.

\section{Key to the known species of Saxiloba}

1 Thallus regularly rosette-forming with radiating lobes with contiguous tips; lobes $0.5-1 \mathrm{~mm}$ wide; surface silvery grey-green; lines of crystal clusters forming a network of closed, isodiametric to elongate chambers; on calcareous rock in usually shady conditions; Caribbean ....................... Saxiloba firmula Thallus irregular in outline with irregular lobes often leaving interspaces; lobes $1-0.1 .5 \mathrm{~mm}$ wide; surface olive-yellow to yellowish grey-green; lines of crystal clusters forming a meandering, labyrinthine network of partially open, elongate to jigsaw-puzzle-shaped chambers; on basalt in more exposed conditions; Hawaii ..... Saxiloba hawaiiensis

Saxiloba firmula (Nyl. ex Müll. Arg.) Lücking, Moncada \& Sipman, comb. nov.

(Fig. 2)

MycoBank MB 835481

三 Porina firmula Nyl. ex Müll. Arg., Bot. Jb. 6: 401. 1885; Verrucaria firmula Nyl., Flora 59: 365. 1876.

Type: Cuba. Unknown locality and date, C. Wright s.n. (G-G00293637, lectotype!, here designated; Lich. Cub. 7b; isolectotypes: G-G00293636, G-G00293638; Lich. Cub. 7).

= Endopyrenium incrassatum Müll. Arg., Bot. Jb. 6: 377 (1885); Dermatocarpon incrassatum (Müll. Arg.) Zahlbr., Cat. Lich. Univers. 1: 218. 1921 [1922].

Type: Cuba. Unknown locality and date, C. Wright s.n. (G-G00291774, lectotype!, here designated; Lich. Cub., Ser. II: 535; isolectotype: G-G00291775; Lich. Cub., Ser. II: 535). 
Description. Thallus saxicolous on calcareous rocks, up to $5-10(-20) \mathrm{mm}$ diam. with regularly radiating lobes with closely contiguous tips; lobes $0.5-0.1 \mathrm{~mm}$ wide; surface silvery grey-green with a network of reticulate lines around isodiametric to elongate chambers (best seen when hydrated). Thallus in section 200-300 $\mu$ m thick with large, up to $100 \mu \mathrm{m}$ high and broad, triangular to rhomboid crystal clusters embedded into the photobiont layer, the latter developed horizontally beneath and vertically between the crystal clusters; above with a 20-30 $\mu \mathrm{m}$ thick, prosoplectenchymatous cortex and below with a $30-50 \mu \mathrm{m}$ thick medulla and a $40-70 \mu \mathrm{m}$ thick, dark brown hypothallus layer. Perithecia erumpent from the thallus and almost up to the ostiolar area covered with a thick thallus layer, up to $0.5 \mathrm{~mm}$ diam.; excipulum 25-35 $\mu \mathrm{m}$ thick, outer parts paraplectenchymatous, pale yellowish, $\mathrm{K}+$ deep orange-red, inner parts prosoplectenchymatous, colourless; involucrellum only
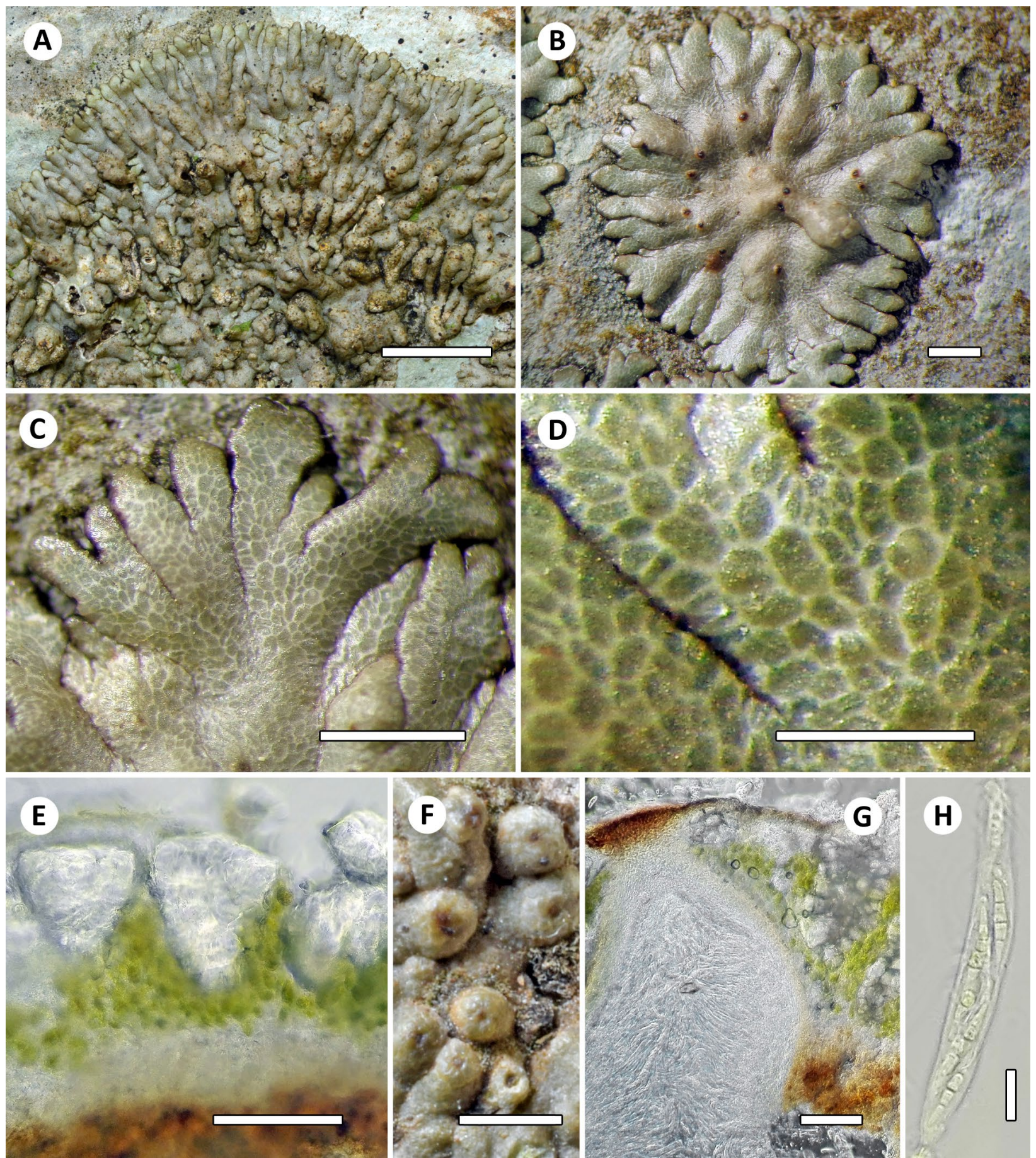

H

Figure 2. Habit of Saxiloba firmula. A - thallus on calcareous rock; B - young thallus with immature perithecia; C-D - thallus lobes hydrated (in D enlarged) to show crystal clusters embedded in a network of hyphae with the photobiont layer beneath; the crystals reflect the greenish color of the photobiont, whereas the pale color of the reticulate lines is caused by the upper cortex; E - thallus section showing disposition of crystal clusters, photobiont layer, upper cortex, medulla and hypothallus; F - perithecia; $\mathrm{G}$ - section through perithecium showing laterally covering thallus layer with details of crystal clusters $\mathrm{H}$, ascus with ascospores. (A - Lücking et al. 41865; B-D - Lücking et al. 41891; E-G - Lücking \& Moncada 45298; H - lectotype). Scales: A $=5 \mathrm{~mm} ; \mathrm{B}-\mathrm{C}, \mathrm{F}=1 \mathrm{~mm} ; \mathrm{D}=0.5 \mathrm{~mm} ; \mathrm{E}, \mathrm{G}=100 \mu \mathrm{m} ; \mathrm{H}=10 \mu \mathrm{m}$. 
developed around the ostiolar area, 30-60 $\mu \mathrm{m}$ thick, paraplectenchymatous, reddish brown with a distinct reddish tinge when seen from the outside. Ascospores 8 per ascus, oblong-fusiform, transversely 3-5(-7)-septate, 15-20(-25) × 3-4(-6) $\mu \mathrm{m}$, hyaline. Pycnidia rare, up to $0.1 \mathrm{~mm}$ diam., appearing as brownish red warts. Conidia oblong-bacillar, non-septate, 3-4 × $1 \mu \mathrm{m}$, hyaline.

Distribution and ecology. Thus far known from Cuba, including Isla de la Juventud (also known as Isle of Pines or Isla de Pinos) and further reported from the Bahamas and Puerto Rico (Müller 1885; Riddle 1923; Gannutz 1970; Mercado-Díaz 2009). Possibly a Caribbean endemic, in Cuba quite common on calcareous rocks in mostly shaded microhabitats in the dry forests of western and central Cuba. In Puerto Rico, it would be expected in similar habitats, but has not been found in recent surveys. According to Gannutz (1970), the Puerto Rican material was collected at El Yunque National Forest, a rather wet forest with a geology dominated by volcanic rock. This would broaden the ecological range for Saxiloba firmula, but since we have not been able to obtain the material corresponding to this record, we are considering these data with care.

Notes. Saxiloba firmula was first introduced as nomen nudum by Nylander (1876) in the genus Verrucaria and shortly after validated by Müller (1885) in the genus Porina. Müller (1885: 401) did not properly describe the unique thallus morphology of the species, likely because the type material had originally been scraped off the substrate and is fragmented into numerous, small pieces in the lectotype and isolectotypes. Müller (1885: 377) described the same species also as Endopyrenium incrassatum, possibly because of the few, young ascomata ('apothecia pauca valde juvenilia offerunt') with small $(18-20 \times 4-6 \mu \mathrm{m})$, 1 -septate ascospores, not realizing the identity of the material. McCarthy (1993) did not mention the name in his treatment of saxicolous Porina species; he annotated the type material in 1992 as 'probably not Porina'.

Riddle (1923) reported the species from Isla de la Juventud (Isle of Pines). One of the two cited collections was reported as '... Cerro San Juan del Mar, Columbia ...' (Riddle 1923: 71), which may cause confusion, as there is indeed such a location in Colombia. However, the material refers to Cerros de San Juán in the Columbia community on Isla de la Juventud (Kallunki 1980; Boom 1996; Sastre de Jesús \& Santiago-Valentín 1996). In the same paper, Riddle (1923) described P. subfirmula Riddle, also from Isla de la Juventud. That species has, however, a very different, crustose thallus morphology (isotype in NY, NY01219352, Britton \& Wilson 15741 checked).

Müller (1885) described (and illustrated the ascospores on the type material as predominantly 5 -septate and 20-30 $\mu \mathrm{m}$ long. In our recently collected material, we found only few thalli with perithecia with the ascospores mostly 3-septate and 15-20 $\mu \mathrm{m}$ long. Annotations on NY specimens by R.C. Harris also indicate 3-septate ascospores and a discrepancy with Müller's description (J. Lendemer, pers. comm. 2020). Revision of the lectotype showed the ascospores to be mostly 3 -septate, more rarely $4-5$-septate, and $15-20(-25) \mu \mathrm{m}$ long. It is therefore unclear how Müller (1885) derived his observations, although based on annotations by R. C. Harris, the material from the Bahamas apparently also features ascospores with more numerous septa (J. Lendemer, pers. comm. 2020).

Specimens examined. BAHAMAS. Andros, Mastic Point and Vicinity; $25^{\circ} 03^{\prime} \mathrm{N}, 77^{\circ} 57^{\prime} \mathrm{W}$; 19-28 March 1907, L. J. K. Brace 7048a (FH). Cockburn Town, Watling's Island; 12-13 March 1907, N. L. Britton \& C. F. Millspaugh 6126 (FH). CUBA. The type material of P. firmula and E. incrassatum. Artemisa: Candelaria, Jardín Botánico Orquideario Soroa; $22^{\circ} 47^{\prime} \mathrm{N}$, $83^{\circ} 01^{\prime} \mathrm{W}, 210 \mathrm{~m}$; on shaded calcareous rock face; 24 March 2017, R. Lücking \& B. Moncada 43034 (B, HAJB). Cienfuegos: Cumanayagua, Las Vegas del Matagua, trail from Lucia's house to Las Lagunas; $21^{\circ} 59^{\prime} 14^{\prime \prime} \mathrm{N}, 80^{\circ} 11^{\prime} 54^{\prime \prime} \mathrm{W}, 665 \mathrm{~m}$; evergreen lower montane (mesophyllous) rain forest, on calcareous rock; 21 March 2018; R. Lücking \& B. Moncada 45155 (B, HAJB), 45157 (B). Caletón de Don Bruno, trail from town towards coastal mangrove; $22^{\circ} 04^{\prime} 16^{\prime \prime} \mathrm{N}, 80^{\circ} 27^{\prime} 44^{\prime \prime} \mathrm{W}, 0-25 \mathrm{~m}$; matorral costero, on calcareous rock; 22 March 2018, R. Lücking \& B. Moncada 45298 (B). Pinar del Río: Rio Guao; 27 February 1911; N. L. Britton et al. 9668 (FH). Viñales, Pinar del Río National Park, Sierra de Quemado, Moncada, $20 \mathrm{~km}$ WSW of Viñales, 'mogote' behind Malagones monument; $22^{\circ} 33^{\prime} \mathrm{N}$, $83^{\circ} 51^{\prime} \mathrm{W}, 180 \mathrm{~m}$; mesophyllous semideciduous forest on karst, on calcareous rock face; 9 April 2016, R. Lücking et al. 41865, 41891 (B, HAJB). Sancti Spiritus: Trinidad, Parque Natural Protejido Topes de Collantes, trail to Pico de Potrerillo; $21^{\circ} 53^{\prime} 17^{\prime \prime} \mathrm{N}$ to $21^{\circ} 54^{\prime} 19^{\prime \prime} \mathrm{N}, 80^{\circ} 00^{\prime} 11^{\prime \prime} \mathrm{W}$ to $80^{\circ} 00^{\prime} 31^{\prime \prime} \mathrm{W}$; $650-860 \mathrm{~m}$; on calcareous rock; 19 March 2018, R. Lücking \& B. Moncada 44918 (B). Isla de la Juventud: SW of Nueva Gerona, Sierra de Casas, Mogote El Abra; $21^{\circ} 85^{\prime} \mathrm{N}, 82^{\circ} 82^{\prime} \mathrm{W}$; April-May 1975, R. Schubert (B, HAL). Cerro San Juán del Mar; 20 February 1916, N.L. Britton \& P. Wilson 14683 (FH, NY). Cerros de Bibijagua; 28 February 1916, N.L. Britton \& P. Wilson 15047 (FH, NY).

\section{Saxiloba hawaiiensis Lücking, Moncada}

\& Flynn, sp. nov.

(Fig. 3)

\section{MycoBank MB 835480}

Diagnosis: Differing from Saxiloba firmula in the irregular thallus outline with the lobes often leaving interspaces, and the surface lines forming a meandering, labyrinthine network with partially open, elongate to jigsaw-puzzle-shaped chambers.

Type: USA. Hawaii, Kauai, Waimea District, Na Pali-Kona Forest Reserve, Mahanaloa Valley; 410 m (1340 ft); disturbed forest dominated by Aleurites with Kokia, Pisonia, Hibiscus, Nototrichium, Psidium, Rubus, Microlepia, and Christella, on shaded basalt face, locally common; 24 August 1992, T. Flynn et al. 5095 (PTBG 1000024450 - holotype; B, WIS - isotypes).

Description. Thallus saxicolous on basalt, up to $10 \mathrm{~mm}$ diam. with irregularly branched lobes usually leaving interspaces; lobes 1.0-1.5 mm wide; surface yellowish olive with meandering, labyrinthine lines forming a network of partially open, elongate to jigsaw-puzzle-shaped chambers. Thallus in section $400-800 \mu \mathrm{m}$ thick with large, up to $300 \mu \mathrm{m}$ high and up to $150 \mu \mathrm{m}$ high broad, narrowly rhomboid crystal clusters embedded into the photobiont layer, the latter developed horizontally beneath and vertically between the crystal clusters; above with a $20-30 \mu \mathrm{m}$ 

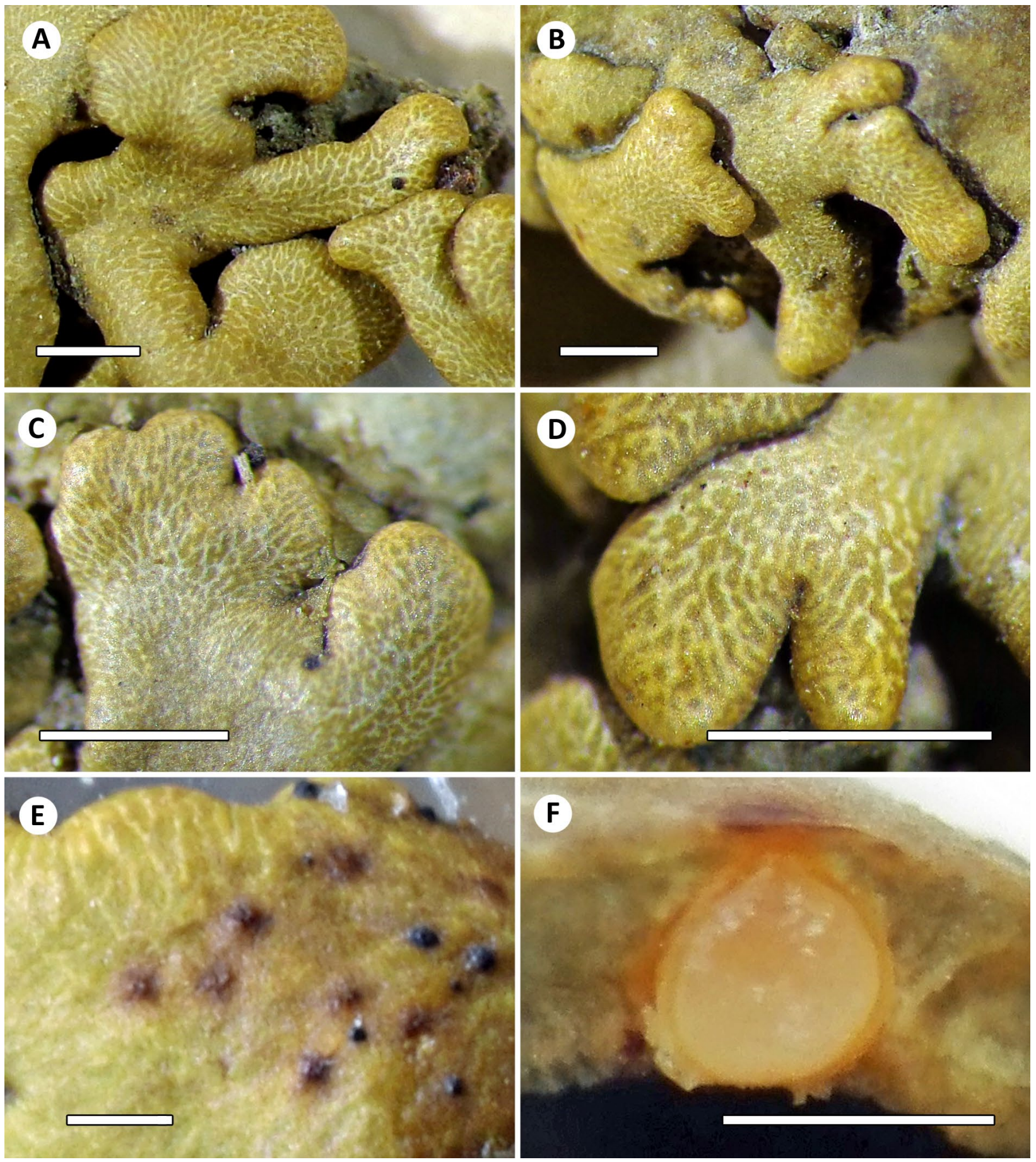

Figure 3. Habit of Saxiloba hawaiiensis (isotype). A-C - thallus fragments removed from basalt; D-E - thallus lobes enlarged to show meandering crystal clusters embedded in a network of hyphae with the photobiont layer beneath; the crystals reflect the greenish color of the photobiont, whereas the pale color of the reticulate lines is caused by the upper cortex; F - young thalli developing atop an old, decaying thallus portion. Scales: A-D $=1 \mathrm{~mm} ; \mathrm{E}-\mathrm{F}=0.5 \mathrm{~mm}$.

thick, prosoplectenchymatous cortex and below with an up to $300 \mu \mathrm{m}$ thick medulla and a $30-50 \mu \mathrm{m}$ thick, brownish black hypothallus layer. Perithecia immersed in the thallus and almost up to the ostiolar area covered with a thick thallus layer, up to $0.6 \mathrm{~mm}$ diam.; excipulum $25-35 \mu \mathrm{m}$ thick, outer parts paraplectenchymatous, yellowish, $\mathrm{K}+$ deep orange-red, inner parts prosoplectenchymatous, colourless; involucrellum only developed around the ostiolar area, 30-50 $\mu \mathrm{m}$ thick, paraplectenchymatous, reddish brown with a distinct reddish tinge when seen from the outside. Ascospores 8 per ascus, oblong-fusiform, transversely 3-septate, $15-20 \times 3.5-4.5 \mu \mathrm{m}$, hyaline. Pycnidia not observed.

Distribution and ecology. Thus far known only from the type locality on the island of Kauai in Hawaii, like the type species growing on shaded rocks, but on volcanic basalt.

Notes. The material here described as Saxiloba hawaiiensis was collected by TWF and colleagues more than 25 years ago, but left unidentified. During a visit by $\mathrm{RL}$ and BM to the National Tropical Botanic Garden on Kauai, the material drew our attention. With the 
subsequent discovery of a similar lichen in Cuba, we were able to finally put a name on the Hawaiian lichen as well, especially as upon close inspection, we discovered the presence of perithecia producing asci and ascospores typical of Porinaceae. Saxiloba hawaiiensis shares with S. firmula the placodioid thallus with the striking surface pattern formed by the columnar thallus crystals. Although we do not have sequence data for this taxon, the irregular lobe configuration, the more robust lobes, the differences in the patterns of the surface lines surrounding the crystalline clusters, and the different substrate and disjunct distribution leave no doubt that this species is distinct from the Caribbean taxon.

\section{Acknowledgements}

Field work in Hawaii by RL and BM was supported by a grant from the National Science Foundation (NSF) to The Field Museum: DEB-1025861 'ATM-Assembling a Taxonomic Monograph: The Lichen Family Graphidaceae'. Field work in Cuba by RL, BM and CV, as well as DNA sequencing work by BM at the Botanischer Garten and Botanisches Museum (BGBM) in Berlin, Germany, was supported by the Verein der Freunde des Botanischen Gartens, Berlin, Germany. We thank Clifford W. Smith for logistic help with field work in Hawaii and Banessa Falcón, Alelí Morales, Susy Fuentes Bazán, Julio León Cabrera, Julio Ramón Godinez Fonseca, Nils Köster and the Jardín Botánico Nacional in Havana, in particular also Cristina Panfet-Valdés, for invaluable assistance regarding field work and logistics in Cuba. PNBS acknowledges the Fundação de Amparo a Ciência e Tecnologia de Pernambuco (FACEPE) for a research grant and the PDSE doctoral sandwich program (CAPES) for a scholarship to perform laboratory and identification work at the Botanischer Garten and Botanisches Museum (BGBM) in Berlin, Germany. David H. Lorence and Dustin Wolkis assisted in gathering photographic data for Saxiloba hawaiiensis. Michaela Schmull and James Lendemer provided information about specimens of Saxiloba firmula housed in FH and NY. Joel A. Mercado-Díaz made usefull comments on an earlier version of this manuscript.

\section{References}

Aptroot, A. \& Bungartz, F. 2007. The lichen genus Ramalina on the Galapagos. The Lichenologist 39: 519-542.

Aptroot, A. \& Cáceras, M. E. S. 2013. Pyrenocarpous lichens (except Trypetheliaceae) in Rondônia. The Lichenologist 45: 763-785.

Aptroot, A. \& Sipman, H. J. M. 1993. Trichotheliaceae (Lichens). Flora of the Guianas. Series E: Fungi and Lichens, Fascicle 2, Koeltz Scientific Books, Königstein, Germany.

Baloch, E. \& Grube, M. 2006. Evolution and phylogenetic relationships within Porinaceae (Ostropomycetidae), focusing on foliicolous species. Mycological Research 110: 125-136.

Baloch, E. \& Grube, M. 2009. Pronounced genetic diversity in tropical epiphyllous lichen fungi. Molecular Ecology 18: 2185-2197.

Boom, B. M. 1996. Botanical expeditions of The New York Botanical Garden. Brittonia 48: 297-307.

Bungartz, F., Giralt, M., Sheard, J. W. \& Elix, J. A. 2016. The lichen genus Rinodina (Physciaceae, Teloschistales) in the Galapagos Islands, Ecuador. The Bryologist 119: 60-93.

Carlquist, S., Baldwin, B. G. \& Carr, G. D. (eds) 2003. Tarweeds \& Silverswords: Evolution of the Madiinae (Asteraceae). St. Louis, Missouri: Missouri Botanical Garden Press.
Chen, Y., Ye, W., Zhang, Y. \& Xu, Y. 2015. High speed BLASTN: an accelerated MegaBLAST search tool. Nucleic Acids Research 43: $7762-7768$.

Dal Forno, M., Bungartz, F., Yánez-Ayabaca, A., Lücking, R. \& Lawrey, J. D. 2017. High levels of endemism among Galapagos basidiolichens. Fungal Diversity 85: 45-73.

Eldredge, L. G. \& Miller, S. E. 1995. How many species are there in Hawaii? Bishop Museum Occasional Papers 41: 3-18.

Follmann, G. 1965. Fensterflechten in der Atacamawuste. Die Naturwissenschaften 52: 434-435.

Frisch, A., Kalb, K. \& Grube, M. 2006. Contributions towards a new systematics of the lichen family Thelotremataceae. Bibliotheca Lichenologica 92: 1-539.

Fryday, A. M. \& Hertel, H. 2014. A contribution to the family Lecideaceae s.lat. (Lecanoromycetidae inc. sed., lichenized Ascomycota) in the southern subpolar region; including eight new species and some revised generic circumscriptions. The Lichenologist 46: 389-412.

Gannutz, T. P. 1970. A study of the lichens of an irradiated rain forest. In Odum, H. T. \& Pigeon, R. F. (eds). A Tropical Rain Forest. A Study of irradiation and Ecology at El Verde, Puerto Rico: D227-D231. Division of Technical Information, U.S. Atomic Energy Commission, Oak Ridge.

Givnish, T. J., Millam, K. C., Theim, T. T., Mast, A. R., Patterson, T. B., Hipp, A. L., Henss, J. M., Smith, J. F., Wood, K. R. \& Sytsma, K. J. 2009. Origin, adaptive radiation, and diversification of the Hawaiian lobeliads (Asterales: Campanulaceae). Proceedings of the Royal Society of London, Series B 276: 407-416.

Grube, M., Baloch, E. \& Lumbsch, H. T. 2004. The phylogeny of Porinaceae (Ostropomycetidae) suggests a neotenic origin of perithecia in Lecanoromycetes. Mycological Research 108: 1111-1118.

Hafellner, J. \& Kalb, K. 1995. Studies in Trichotheliales ordo novus. Bibliotheca Lichenologica 57: 161-186.

Harada, H. 2015. Saxicolous and corticolous species of Porina (lichenized Ascomycota, Porinaceae) of Japan (part 1). Lichenology 14: $1-26$.

Harada, H. 2016: Saxicolous and corticolous species of Porina (Lichenized Ascomycota, Porinaceae) of Japan (Part 2). Lichenology 14: $91-118$.

Harris, R. C. 2005. Some name changes in Porina s.lat. Opuscula Philolichenum 2: 15-16.

Sastre de Jesús, I. \& Santiago-Valentín, E. 1996. Botanical explorations of Puerto Rico by NL Britton and EG Britton: their significance in plant conservation, horticulture, and education. Brittonia 48: 322-336.

Johnson, M. P. \& Raven, P. H. 1973. Species number and endemism: The galápagos archipelago revisited. Science 179: 893-895.

Kallunki, J. A. 1980. Cuban plant collections of J. A. Shafer, N. L. Britton \& P. Wilson. Brittonia 32: 397-420.

Katoh, K. \& Standley, D. M. 2013. MAFFT multiple sequence alignment software version 7: improvements in performance and usability. Molecular Biology and Evolution 30: 772-780.

Knope, M. L., Morden, C. W., Funk, V. A. \& Fukami, T. 2012. Area and the rapid radiation of Hawaiian Bidens (Asteraceae). Journal of Biogeography 39: 1206-1216.

Kraichak, E., Huang, J. P., Nelsen, M., Leavitt, S. D. \& Lumbsch, H. T. 2018. A revised classification of orders and families in the two major subclasses of Lecanoromycetes (Ascomycota) based on a temporal approach. Botanical Journal of the Linnean Society 188: 233-249.

Lerner, H. R., Meyer, M., James, H. F., Hofreiter, M. \& Fleischer, R. C. 2011. Multilocus resolution of phylogeny and timescale in the extant adaptive radiation of Hawaiian honeycreepers. Current Biology 21: 1838-1844.

Lücking, R. 1998. Additions and corrections to the knowledge of the foliicolous lichen flora of Costa Rica. The genus Trichothelium (lichenized Ascomycetes: Trichotheliaceae). Nova Hedwigia 66: $375-417$. 
Lücking, R. 2019. Stop the abuse of time! Strict temporal banding is not the future of rank-based classifications in Fungi (including lichens) and other organisms. Critical Reviews in Plant Sciences 38: 199-253.

Lücking, R. \& Vězda, A. 1998. Taxonomic studies in foliicolous species of the genus Porina (lichenized Ascomycotina: Trichotheliaceae) II. The Porina epiphylla group. Willdenowia 28: 181-225.

Lücking, R., Mangold, A., Rivas Plata, E., Parnmen, S., Kraichak, E. \& Lumbsch, H. T. 2015. Morphology-based phylogenetic binning to assess a taxonomic challenge: a case study in Graphidaceae (Ascomycota) requires a new generic name for the widespread Leptotrema wightii. Botanical Journal of the Linnean Society 436: 436-443.

Lücking, R., Moncada, M. \& Smith, C. W. 2017. The genus Lobariella (Ascomycota: Lobariaceae) in Hawaii: late colonization, high inferred endemism, and three new species. The Lichenologist 49: 673-691.

Makhija, U., Adawadkar, B. \& Patwardhan, P. G. 1994. The lichen genus Porina (family Trichotheliaceae) from India. Journal of Economic and Taxonomic Botany 18: 521-545.

Malcolm, W. M., Elix, J. A. \& Owe-Larsson, B. 1995. Labyrintha implexa (Porpidiaceae), a new genus and species from New Zealand. The Lichenologist 27: 241-248.

McCarthy P. M. 1993. Saxicolous species of Porina Müll. Arg. (Trichotheliaceae) in the Southern Hemisphere. Bibliotheca Lichenologica 52: $1-134$

McCarthy, P. M. 1995. A reappraisal of Clathroporina Müll. Arg. (Trichotheliaceae). The Lichenologist 27: 321-350.

McCarthy, P. M. 2001. Trichotheliaceae. In McCarthy, P. M. (ed.). Flora of Australia. Volume 58A, Lichens 3: 105-157. ABRS/CSIRO Australia, Melbourne.

McCarthy, P. M. 2003. Catalogue of the Lichen Family Porinaceae. Bibliotheca Lichenologica 87: 1-164.

McCarthy, P. M. \& Elix, J. A. 1996. Myeloconis, a new genus of pyrenocarpous lichens from the tropics. The Lichenologist 28: 401-414.

McCarthy, P. M. \& Malcolm, W. M. 1997. The genera of Trichotheliaceae. The Lichenologist 29: 1-8.

Mercado-Díaz, J. A. 2009. Preliminary Checklist of Lichens and Lichenicolous Fungi of Puerto Rico (Version 1, July 2009). Published by the author, San Juan, Puerto Rico.

Mercado-Díaz, J. A., Lücking, R., Moncada, B., Widhelm, T. J. \& Lumbsch, H. T. 2020. Elucidating species richness in lichen fungi: the genus Sticta (Ascomycota: Peltigeraceae) in Puerto Rico. Taxon. https://doi.org/10.1002/tax.12320 [online first]

Moncada, B., Reidy, B. \& Lücking, R. 2014. A phylogenetic revision of Hawaiian Pseudocyphellaria (lichenized Ascomycota: Lobariaceae) reveals eight new species and a high degree of inferred endemism. The Bryologist 117: 119-160.

Morden, C. W., Weniger, D. \& Gardner, D. E. 2003. Phylogeny and biogeography of Pacific Rubus subg. Idaeobatus (Rosaceae) species: investigating the origin of the endemic Hawaiian raspberry R. macraei. Pacific Science 57: 181-197.

Müller, J. 1885. Pyrenocarpeae Cubenses a cl. C. Wright lectae. Botanische Jahrbücher 6: 375-421.
Nelsen, M. P., Lücking, R., Andrew, C. J., Aptroot, A., Cáceres, M. E. S., Mercado-Díaz, J. A., Rivas Plata, E. \& Lumbsch, H. T. 2014. Molecular phylogeny reveals the true colours of Myeloconidaceae (Ascomycota: Ostropales). Australian Systematic Botany 27: 38-47.

Nylander, W. 1876. Circa Pyrenocarpeos in Cuba lectos a cl. C. Wright. Flora 59: 364-365.

O'Grady, P. \& DeSalle, R. 2008. Out of Hawaii: the origin and biogeography of the genus Scaptomyza (Diptera: Drosophilidae). Biology Letters 4: 195-199.

Parent, C. E. \& Crespi, B. J. 2009. Ecological opportunity in adaptive radiation of Galapagos endemic land snails. The American Naturalist 174: 898-905.

Pax, D. L., Price, R. A. \& Michaels, H. L. 1997. Phylogenetic position of the Hawaiian Geraniums based on rbcL sequences. American Journal of Botany 84: 72-78.

Rambaut, A. \& Drummond, A. J. 2012. FigTree Version 1.4.0. http:// tree.bio.ed.ac.uk/software/figtree

Riddle, L. W. 1923. The lichens of the Isle of Pines. Mycologia 15: 68-88.

Rivas Plata, E., Lücking, R. \& Lumbsch, H. T. 2008. When family matters: an analysis of Thelotremataceae (lichenized Ascomycota: Ostropales) as bioindicators of ecological continuity in tropical forests. Biodiversity and Conservation 17: 1319-1351.

Rivas Plata, E., Lücking, R., Sipman, H. J. M., Mangold, A., Kalb, K. \& Lumbsch, H. T. 2010. A world-wide key to the thelotremoid Graphidaceae, excluding the Ocellularia-Myriotrema-Stegobolus clade. The Lichenologist 42: 139-185.

Smith, C. W. 2013. Checklist of lichens and lichenicolous fungi of Hawaii (USA). http://www.biologie.uni-hamburg.de/checklists/ oceania/usa_hawaii_l.htm

Sobreira, P. N. B., Cáceres, M. E. S., Maia, L. C. \& Lücking, R. 2018. Flabelloporina, a new genus in the Porinaceae (Ascomycota, Ostropales), with the first record of $F$. squamulifera from Brazil. Phytotaxa 358: 67-75.

Stamatakis, A. 2014. RAxML version 8: a tool for phylogenetic analysis and post-analysis of large phylogenies. Bioinformatics 30: 1312-1313.

Tye, A. \& Francisco-Ortega, J. 2011. Origins and evolution of Galapagos endemic vascular plants. In Bramwell, D. \& Caujapé-Castells, J. (eds). The Biology of Island Floras: 89-153. Cambridge University Press, Cambride.

Vogel, S. 1955. Niedere „Fensterpflanzen” in der südafrikanischenWüste. Eine ökologische Schilderung. Beitraege zur Biologie der Pflanzen 31: 45-135.

Vondrák, J. \& Kubásek, J. 2013. Algal stacks and fungal stacks as adaptations to high light in lichens. The Lichenologist 45: 115-124.

Wagner, W. L. \& Funk, V. A. (eds) 1995. Hawaiian Biogeography: Evolution on a Hot Spot Archipelago. Smithsonian Institution Press, Washington DC.

Weber, W. A. 1986. The lichen flora of the Galapagos Islands, Ecuador. Mycotaxon 27: 451-49. 